\title{
From alchemy to chemistry
}

\author{
Andreas Libavius and the Transformation \\ of Alchemy: Separating Chemical Cultures \\ with Polemical Fire \\ by Bruce T. Moran \\ Science History Publications: 2007. \\ 344 pp. $\$ 49.95$

\section{Chymists and Chymistry: Studies in the History of Alchemy and Early Modern Chemistry} \\ edited by Lawrence M. Principe \\ Chemical Heritage Foundation/Science \\ History Publications: 2007. 274 pp. $\$ 45$
}

\section{Philip Ball}

The Communist Party of Britain (MarxistLeninist), it has been said, had no scorn for right-wingers to match that it reserved for the parenthesis-free Communist Party of Britain. To judge from the writings of the German chymist Andreas Libavius, little has changed. The invective he hurled at, and received from, contemporaries whose views we now struggle to distinguish, is a sober reminder of how historical distance turns violent academic spats into hair-splitting.

Libavius (c.1550-1616) has always been a marginal figure in histories of chemistry. He usually features as the author of Alchemia (1597), commonly called the first textbook of chemistry. The book served as the model for Jean Beguin's Tyrocinium Chymicum (1610) and Nicolas Lémery's Cours de Chimie (1675), in which one can start to see something like early modern chemistry taking shape.

As Bruce Moran argues in Andreas Libavius and the Transformation of Alchemy, his majestic survey of Libavius's life and work, Alchemia is by no means the key to Libavius's role in chemical history. By awarding it a place in chemistry's lineage, historians have imposed some apparent order on the emergence of the subject from the sooty fumes of alchemy. Moran makes a convincing case that this is an artificial narrative. The transition was unruly - in all respects - and mocks attempts to label its players as progressives or conservatives.

Moran's scholarly efforts are all the more valuable because they could seem in some ways unrewarding. Libavius was not an especially innovative thinker. He spent little time in the laboratory and what he wrote on chymistry - the transitional discipline between alchemy and chemistry - was, he admitted, taken mostly from other sources. He expended much energy in furious disputes, involving the kind of bitter, frequently scatological diatribes that, while amusing at first, soon become tiresome. "You will never leave the contest unless you have left behind a barb," wrote the Parisian doctor Jean Riolan in 1606 of Libavius. All this, Moran admits, can make Libavius seem "more like an off-putting sour-puss than a compelling or attractive historical figure".

Yet in these battles Libavius reveals a great deal about the issues - philosophical, political and religious - on which the establishment of chemistry as an academic discipline hinged.

Libavius's sharp tongue recalls that of the figure whose writings triggered much of the argument: the Swiss alchemical physician Paracelsus (1493-1541). Medicine by the end of the sixteenth century is often depicted as split into two camps: the traditionalists, who
Parisian medical faculty. He seems almost to have courted enemies by taking positions that were superficially contradictory. He wanted chymistry to be considered a serious liberal art, yet called it "a bilge-flood and chaos of impurity and human dregs". His damning assessment was, however, aimed at chymistry as he saw it being done, polluted by infernal Paracelsians. He thought it should be a science that rejected mystical speculation and combined manual arts learnt through experience and philosophical principles derived from Aristotle.

The book isn't an introductory read. You could be misled, for example, if you do not already know that by 'Ramon Lull' and 'Roger Bacon' Moran means a body of writings attributed, often apocryphally, to those authors, or that Basil Valentine is probably a pseudonym of a late-sixteenth-century writer. And he takes it for granted that the reader will recognize Libavius's portrayal of Paracelsianism to be mostly a caricature. But the book opens up a neglected period that chemical historians have been too eager to skate over in the rush to get from Paracelsus to Robert Boyle.

Indeed, the role of alchemy in the genesis of chemistry has become a hot topic, as Lawrence Principe says in his introduction to Chymists and Chymistry. Time was when those who studied it risked being thought of as lacking in judgement, or worse. Several recent books, such as William Newman's study of Daniel Sennert's atomistic theories, Atoms and Alchemy, have shown that 'modern' theories of matter and chemical change actually grew from alchemy, rather than supplanting it.

Chymists and Chymistry is the product of a major conference, hosted by the Chemical Heritage Foundation in Philadelphia in 2006; it brings together papers with an immense scope, straddling the eras of Paracelsus and Antoine Lavoisier. Particularly welcome are contributions on archaeological analyses of and Galen, and the chemical physicians ('iatrochemists') who used Paracelsian cures. This is too simple a picture, Moran shows. There were "Hippocratic hermeticists, Galenochemists, natural and hermetic chymiatrists" and others, all denouncing one another venomously.

Libavius had to be pugnacious because he didn't really fit into any camp. He despised Paracelsians, but was highly critical of the traditionalists and came to the defence of the Paracelsian court physicians to Henry IV of France when they were attacked by the Galenist alchemical equipment - a neglected arena in a subject usually reliant on text alone. As one of the contributors, Marcos Martinón-Torres of University College London, observes, pioneer historians of alchemy were often chemists who could be historically naïve; the danger now is that the subject be conducted only by historians who ignore materials science. Libavius was right in that respect: we need both books and benchtops.

Philip Ball is a consultant editor at Nature. His books include The Devil's Doctor: Paracelsus and the World of Renaissance Magic and Science. 